\title{
Demographic Discriminators of Service Quality in Local Government
}

\author{
Safiek Mokhlis ${ }^{1}$ \\ ${ }^{1}$ Faculty of Management and Economics, Universiti Malaysia Terengganu, Kuala Terengganu, Malaysia \\ Correspondence: Safiek Mokhlis, Faculty of Management and Economics, Universiti Malaysia Terengganu, \\ 21030 Kuala Terengganu, Malaysia. Tel: 60-9-668-4823. E-mail: safiek@umt.edu.my
}

Received: February 13, 2012

Accepted: March 14, 2012 Published: May 1, 2012

doi:10.5539/emr.v1n1p131

URL: http://dx.doi.org/10.5539/emr.v1n1p131

\begin{abstract}
Few services, if any, will have customers who all have exactly the same needs and who use the services in exactly the same way. Rather, services will face distinct and different customer segments. This study aimed to discriminate on key demographic variables to determine which dimensions of service quality in local government are most important to different demographic segments. The data were collected by means of a self-administered questionnaire survey conducted among residents of Khok Pho municipality in Pattani Province, southern Thailand. Four separate discriminant analysis were performed to ascertain which dimensions of service quality are potentially more important to different demographic groups. Results indicated that three discriminant functions - gender, age, and education - were statistically significant. Strategic issues in managing service quality within the local government context are identified and discussed.
\end{abstract}

Keywords: municipal council, local government, service quality, demographics

\section{Introducation}

Local government undeniably plays a vital role in the growth of society as a whole, as well as in the stability and improvement of people's daily lives. Many public services supporting individual and community well-being, such as management of refuse and sewage disposal facilities, community health, environmental control, construction, maintenance of community halls and similar facilities, and development of roads and recreational parks; are delivered through local government mechanisms, making this sector responsible for much quality of life expectation.

The role of local government authorities in providing various public services in the rapid changes of environment, contributes to the complexities of its functions. These complexities are further exacerbated by difficulties in measuring outcomes, decrease revenues, increased responsibilities, growing public distrust of their capabilities, a lack of freedom to act in an arbitrary fashion, and a requirement for decisions to be based in law (Teicher, Hughes, \& Dow, 2002). At the same time, local authorities are under increasing pressure to demonstrate that their services are customer-focused and that continuous improvement in service delivery is being made (Fountain, 2001).

Fundamental to service quality is the belief that an organization exists to serve its customers, that is, if it intends to enhance their public image and maximize customer satisfaction. Service quality concept stresses that customers are worth listening to and that they are the best judges of the quality of the services they use. Heskett (1987) indicates how a service should begin with an intimate understanding of the target market. This understanding is critical for identifying customer needs and priorities, designing and implementing effective and efficient service models, and monitoring and evaluating progress in service delivery.

Revealing the profile of customer segments will represent the first area of concern in developing service delivery and service improvement programs. Bowen and Hedges (1993) noted that the importance of various quality improvements differs among customer segments. Ignoring the way in which that service must vary to fit the needs of different segments of the customer base would be a costly mistake. Pointing out the importance of understanding the customers and their relationship to resource allocation for service improvement, Berry, Parasuraman, and Zeithaml (1994, p. 33) noted the following:

"One of the most common service-improvement mistakes [...] is to spend money in ways that do not 
improve service. Aside from being wasteful, such spending hurts the credibility of the service-improvement cause. When invested monies do not produce results, there is little incentive to spend more."

Avoiding such mistakes requires the organizations to optimally allocate their limited available resources to the most important service quality dimensions across different customer segments. One possible method of determining which service quality dimensions are more important to different groups of customers is by utilizing customer demographics (Bowen \& Hedges, 1993). This study aims to examine customers' perceived importance of service quality of local government - an environment that differs from the business sector where service quality so often has been studied and the findings incorporated into practice. Specifically, the study attempts to discriminate on key demographic variables - gender, age, education attainment, and income - to determine which dimensions of service quality are most important to different demographic segments.

\subsection{Service Quality}

Most of the recent work on service quality in marketing can be credited to the pioneering and continuing work of Parasuraman, Berry and Zeithaml. In a seminal work, Parasuraman, Zeithaml, and Berry (1985) developed a Gap Model by synthesizing the expectation-disconfirmation theory concerning consumer satisfaction and previous explorations of the dimensions of service quality. They identified 97 attributes which were found to have an impact on service quality. These attributes were the criteria that are important in molding customers' expectations and perceptions on delivered service. All these attributes fit into ten dimensions of service quality. These dimensions are: (1) tangible features, (2) reliability, (3) responsiveness, (4) communication, (5) credibility, (6) security, (7) competence, (8) courtesy, (9) understanding, and (10) access.

From that initial research, Parasuraman et al. (1988) developed a service quality instrument called SERVQUAL. The scale combined ten components into five generic dimensions of service quality (refer Table 1) which they claimed "provides a basic skeleton [...] which can be adapted or supplemented to fit the characteristics or specific research needs of a particular organization" (p. 31). These dimensions are defined. The SERVQUAL scale consisted of 22 pairs of statements which measure customer expectations and perceptions of service delivered on a seven- or nine-point Likert scale. For each pair of statements, the gap difference (E-P) between the two scores is calculated. The idea is that the service is good if perceptions meet or exceed expectations and problematic if perceptions fall below expectations.

Since its inception, SERVQUAL has been widely used in replication studies in a variety of industrial, commercial and not-for-profit settings, to assess quality of service provision in terms of what customers expect and what they actually receive (for an excellent review, see Ladhari, 2009). The primary value of SERVQUAL lies in its powerful benchmarking, diagnostic, and prescriptive tools. Notwithstanding its widespread impact on business and academia, SERVQUAL has been subjected to numerous criticisms, both the theoretical and operational aspects. For example, Brown, Churchill, and Peter (1993) have suggested measurement problems in the use of difference scores; Cronin and Taylor (1992) have suggested that service quality can be predicted adequately by using perceptions alone rather than using difference scores; and Carman (1990) has suggested that in specific service situations, it may be necessary to delete or modify some of the SERVQUAL dimensions or even introduce new ones. Moreover, in cross-sectional studies, measuring the gap between expectations and performance can be problematic. Since data are generally collected subsequent to the service encounter, questions about service expectations may be based on memory or biased by actual services received (Andaleeb \& Basu, 1994).

In response to critical SERVQUAL analysis, Cronin and Taylor (1992) introduced the SERVPERF instrument, based upon solely performance perception ratings. Based on the empirical evidence across four industries (banks, pest control, dry cleaning, and fast food), Cronin and Taylor (1992) concluded that the performance based measurement approach (SERVPERF) is more in conformance with the existing attitude and customer satisfaction literature and is superior to the perception-expectation gap (SERVQUAL) approach. The SERVPERF scale has outperformed the SERVQUAL scale in the aspect of the number of items to be measured, which have been reduced by $50 \%$, it is also able to explain greater variance in the overall service quality measured through the use of a single-item scale (Jain \& Gupta, 2004). Other studies have also shown that SERVPERF instrument empirically superior to the SERVQUAL scale across several service industries (e.g. Elliott, 1995; Brady, Cronin, \& Brand, 2002; Paul, 2003; Jain \& Gupta, 2004; Gilbert, Veloutsou, Goode, \& Moutinho, 2004).

\subsection{Demographics as Segmentation Variables}

Demographics continue to be one of the most popular and well-accepted bases for segmenting customers and markets (Kotler \& Armstrong, 2008). By specifically identifying the key demographics of one's target market, a 
basic profile of the targeted customer emerges. Even if other types of segmentation variables are used (e.g. behavioral, psychographic, and geographic); a marketer must know and understand demographics to assess the size, reach and efficiency of the target market (Kotler \& Armstrong, 2008). Moreover, demographics are easier to measure than other segmentation variables (Pol, 1991).

Gender, age, education attainment, and income are the most frequently used demographic variables for segmenting the market. Gender is a simple, yet critical demographic variable, since men and women can behave differently as consumers. Male and female differ in their attitudes and behavior based on the genetic characters and some part on socialization. Males tend to be selective processors of information, whereas females tend to be comprehensive processors of information (Evans, Jamal, \& Foxall, 2006). Age segmentation allows a marketer to determine how wants and needs change as an individual matures (Evans et al., 2006). Age influences consumers' decision when they got information, and it is an important condition for estimate service quality (Grazier, Richardson, Martin, \& Diehr, 1986). Education has also been a popular segmentation variable utilized by a myriad of product and service marketers. Education influences a person's thinking in making a decision, and can strongly affect a person's preferences and evaluation of products and services (Hawkins \& Mothersbaugh, 2010). Income has also seen as an effective segmentation base because of its ability to predict a person's willingness to purchase.

Previous studies have shown that demographic variables are related to service quality perceptions. Spathis, Petridou, and Glaveli (2004) found that gender affects service quality perceptions and the relative importance attached to various banking service quality dimensions. Butler, Oswald, and Turner (1996) reported significant effects of gender and age on perceived health-care service quality, while Stafford (1996) found that age and gender were significantly related to different factors of bank service quality.

Customers with higher incomes and levels of education may develop their own sophisticated and accurate estimates of what to expect from a service (Keaveney \& Parthasarathy, 2001). For example, customers with higher incomes may more frequently use services or a greater variety of services. In contrast, customers with lower incomes and less education had ambiguous expectations and their ability to learn from experience was limited (Hoch \& Deighton, 1989). In addition, Keaveney and Parthasarathy (2001) found that lower income and less educated customers' assessments remained uncertain and their evaluations of the service more vulnerable to instances of dissatisfaction.

Taken together, all of the aforementioned studies provide clear evidence that service quality perceptions tend to vary across customer segments by different demographic characteristics. It should to be noted however, that these previous findings are specific to certain service sectors; none of these studies focused exclusively on service quality in local government. This is the research gap toward which the present study will attempt to fill. This study is therefore a contribution to the service quality literature in this area.

\section{Method}

\subsection{The Instrument}

A structured questionnaire was prepared for use in the survey based on literature review and objectives of the study. The SERVQUAL instrument that was designed by Parasuraman et al. (1988) was used to measure service quality. Perceptions-only $(\mathrm{P})$ score rather than gap score (P-E) was used since the perceptions only scale was the best measure when maximizing predictive power is the major objective (Parasuraman, Zeithaml, \& Berry, 1994). Scale items were rated on seven-point Likert scales in a structured format. Each of the 22 items was anchored at the numeral 1 with the verbal statement 'Strongly Disagree' and at the numeral 7 with the verbal statement 'Strongly Agree'. Demographic information was collected which included gender, age, marital status, education attainment, income level, and occupation.

\subsection{Sampling Procedure}

Residents of Khok Pho municipality in Pattani Province, southern Thailand, were taken as study sample. The total number of household in Khok Pho is estimated at 558. According to the guidelines set by Krejcie and Morgan (1970), the required sample size for a population of 550 to 600 is 234 or $41.9 \%$ of the population. The survey was administered in February 2009 to a sample of 234 households with the help of three field assistants. From each household, only one individual, the head or the representative of the household was interviewed. The purpose of this was to avoid imitation or repetition of responses among the respondents and to obtain different views. Interviews were conducted by means of a structured questionnaire. The respondents were discreetly and politely approached with the purpose of the study being explained to them. The respondents were then asked if they would voluntarily participate in this study. If they were unable to participate due to time constraint, the 
researcher would approach them again at another time.

\section{Results}

\subsection{Sample characteristics}

The sample consisted of 234 respondents of which approximately half were males $(53 \%)$ and females (47\%), with the largest age group between 46 and 55 years old (34.6\%). Regarding the level of education, most of the respondents were primary school leavers $(38.5 \%), 30.3 \%$ had completed upper secondary level, $19.2 \%$ had a diploma and $12 \%$ had a graduate degree. The majority of respondents (35\%) reported income between 5,000 and 6,999 Baht per month. Finally, most of the people in the study were businessman (56\%) and farmers (22.6\%). Several also worked in the public sector $(13.7 \%)$ whereas only $7.3 \%$ were employees in the private sector.

\subsection{Factor Analysis}

Exploratory factor analysis with principal component method was utilized in this study to extract a small number of latent variables (factors) from a large number of observed variables (22-items on the SERVQUAL). A first step in factor analysis is visual examination of the correlations, identifying those that are statistically significant. All correlations are above 0.3, which is considered substantial for factor analysis (Hair, Anderson, Tatham \& Black, 1998). The next step involves assessing the overall significance of the correlation matrix with Bartlett test of sphericity. The results were significant at $\mathrm{p}<0.001,\left(\chi^{2}=2589.24\right)$, which further confirmed that the data were suitable for factor analysis. Finally, KMO measure of sampling adequacy was computed to quantify the degree of intercorrelations among the variables, and the results indicate an index of 0.88 . Since a high-KMO value (close to 1.0) is achieved, the dataset is appropriate for factor analysis (Hair et al. 1998).

The analysis converged in sixteen iterations and resulted in five homogeneous sub-scales (see Table 2). The five factors were summarily named as follows: Empathy (5 items), Tangibles (5 items), Assurance (4 items), Reliability (4 items) and Responsiveness (4 items). The five factors accounted for $67.77 \%$ of the variation in the data generated, which satisfies the percentage of variance criterion for social science research (Hair et al. 1998). Examining the individual items, only one out of the 22 items loaded incorrectly on the dimensions extracted in the study by Parasuraman et al. (1988).

To assess the internal consistency or reliability of those factors, Cronbach's coefficient alpha was computed for each of the five factors. The values of Cronbach's alpha lies between 0 and 1 , and the acceptable alpha value should be at least 0.7 (Hair et al. 1998). Results show that coefficient alphas for the five factors were in the range from 0.816 to 0.885 , implying high internal consistency reliability.

Table 1. Summary of factor analysis

\begin{tabular}{lccccc}
\hline & No. of item & $\begin{array}{c}\text { Factor } \\
\text { loadings }\end{array}$ & Eigenvalue & $\begin{array}{c}\text { Variance } \\
\text { explained (\%) }\end{array}$ & $\begin{array}{c}\text { Cronbach's } \\
\text { alpha }\end{array}$ \\
\hline Empathy & 5 & $0.683-0.821$ & 7.420 & 15.287 & 0.885 \\
Tangibles & 5 & $0.714-0.809$ & 2.190 & 15.209 & 0.865 \\
Assurance & 4 & $0.704-0.829$ & 2.037 & 12.869 & 0.843 \\
Reliability & 4 & $0.738-0.811$ & 1.722 & 12.433 & 0.835 \\
Responsiveness & 4 & $0.695-0.821$ & 1.540 & 11.973 & 0.816 \\
\hline
\end{tabular}

\subsection{Discriminant Analysis}

To ascertain which dimensions of service quality are potentially more important to different demographic groups, four separate discriminant analyses were conducted. The resulting discriminant model will allow for a precise determination of the variables associated with particular group membership (e.g. male vs. female). From this information, services managers may be able to develop better marketing strategies in attempting to improve organization performance.

Results of the discriminant analyses are presented in Table 3; and factor score means and standard deviations by subgroup are shown in Table 4. Test statistics are significant for gender, age, and education, indicating that each of these three demographic variables discriminated successfully among different factors of service quality.

Three predictor variables (empathy, tangibles, and reliability) are useful for discriminating between the sexes. 
For all three of the significant factors, factor score means are higher for males than for females, that is, the male customers felt that the local authority performed better in these three factors than female customers. The largest perception difference between male and female towards service quality was empathy (mean difference $=0.52$ ).

Age discriminated successfully for four of the service quality factors (empathy, tangibles, reliability, and responsiveness), albeit three of these factors (empathy, tangibles, and responsiveness) are significant only at $\mathrm{p}<$ 0.10 level. For these four significant factors, the younger age group (below 35) had a relatively lower factor score mean than those of other two groups.

Education also proved to be a discriminating variable; the three significant factors were tangibles, assurance, and reliability. The secondary-educated group had a higher factor score mean than the other groups on tangibles. For assurance, it seemed that the factor score mean for the primary-educated group was lower than those of other two groups. The tertiary-educated group had a lower factor score mean than the other two groups on reliability dimension.

For income, the test statistic was not significant. That is, the discriminant function was unable to detect differences in service quality importance between the two income categories. Consequently, it cannot be concluded that people with different levels of income perceive dimensions of service quality differently.

Table 2. Discriminant analysis results

\begin{tabular}{llllc}
\hline & \multicolumn{3}{c}{ Discriminating variable (F-ratios) } \\
\cline { 2 - 4 } & Gender & Age & Education & Income \\
\hline Empathy & $12.637 * * *$ & $2.733 *$ & 0.887 & 0.006 \\
Tangibles & $7.389 * * *$ & $2.384 *$ & $3.139 * *$ & 0.059 \\
Assurance & 0.488 & 0.315 & $4.552 * *$ & 0.698 \\
Reliability & $4.501 * *$ & $6.564 * * *$ & $2.977 *$ & 0.282 \\
Responsiveness & 2.333 & $2.581 *$ & 0.443 & 0.023 \\
\hline Wilks lambda & 0.935 & 0.925 & 0.907 & 0.994 \\
Chi-square & $15.452 * * *$ & $17.859 * *$ & $22.335 * * *$ & 1.391 \\
\hline
\end{tabular}

$* * *$ significant at $\mathrm{p}<0.01 ; * *$ significant at $\mathrm{p}<0.05 ; *$ significant at $\mathrm{p}<0.10$

Table 3. Factor score means

\begin{tabular}{lccccccccccc}
\hline & \multicolumn{2}{c}{ Gender } & \multicolumn{3}{c}{ Age } & \multicolumn{3}{c}{ Education } & \multicolumn{3}{c}{ Income } \\
\cline { 2 - 11 } & Male & Female & $<35$ & $36-45$ & $>46$ & Pr & Snd & Ter & $<6,999$ & $>7,000$ \\
\hline \multirow{2}{*}{ Empathy } & 4.27 & 3.75 & 3.69 & 4.02 & 4.16 & 3.97 & 4.18 & 3.96 & 4.02 & 4.04 \\
& $(1.13)$ & $(1.11)$ & $(1.08)$ & $(1.18)$ & $(1.14)$ & $(1.24)$ & $(1.19)$ & $(0.98)$ & $(1.24)$ & $(1.00)$ \\
Tangibles & 4.43 & 4.07 & 4.01 & 4.22 & 4.39 & 4.16 & 4.51 & 4.14 & 4.28 & 4.24 \\
& $(1.04)$ & $(0.96)$ & $(1.07)$ & $(1.05)$ & $(0.97)$ & $(1.07)$ & $(1.05)$ & $(0.88)$ & $(1.06)$ & $(0.96)$ \\
Assurance & 3.72 & 3.61 & 3.56 & 3.73 & 3.67 & 3.40 & 3.88 & 3.80 & 3.62 & 3.74 \\
& $(1.14)$ & $(1.09)$ & $(1.08)$ & $(1.17)$ & $(1.10)$ & $(1.04)$ & $(1.15)$ & $(1.11)$ & $(1.17)$ & $(1.03)$ \\
Reliability & 4.38 & 4.09 & 3.75 & 4.38 & 4.34 & 4.37 & 4.33 & 4.00 & 4.21 & 4.29 \\
& $(1.07)$ & $(0.97)$ & $(1.14)$ & $(0.93)$ & $(1.00)$ & $(1.04)$ & $(1.03)$ & $(0.99)$ & $(1.05)$ & $(1.01)$ \\
Responsiveness & 3.84 & 3.64 & 3.45 & 3.83 & 3.81 & 3.78 & 3.80 & 3.66 & 3.75 & 3.73 \\
& $(0.95)$ & $(0.99)$ & $(0.86)$ & $(0.97)$ & $(1.00)$ & $(1.11)$ & $(0.90)$ & $(0.85)$ & $(1.02)$ & $(0.89)$ \\
\hline
\end{tabular}

Note: Numbers in parentheses are standard deviation.

Pr: Primary; Snd: Secondary; Ter: Tertiary

\section{Discussion}

The relation between customer perceptions of service quality and customer characteristics is the key for local government authorities to develop effective quality improvement strategies. Different segments of customers 
have different levels of perceptions towards different service quality dimensions; hence it does not make sense to treat them all as being the same. As the results of this study indicate, gender, age and education were significant in differentiating among dimensions of service quality. Overall, these findings suggest that local authorities need to take the views of demographic segments into account if they want to maximize perceived service quality.

Gender was able to discriminate three dimensions of service quality namely empathy, tangibles and reliability. An examination of factor score means reveal that that females have a lower perception mean than males. It may suggest that the requirement of personal interaction, physical appearance and reliable services may be higher and more importance to females than males when transacting with the local authority. Two of the factors, assurance and responsiveness, seem equally important to both sexes. Consequently, focussing on customer-employee relationships might be a highly effective strategy to maximize quality perceptions of both men and women.

Age of respondents was also a significant discriminator for four service quality factors. The factor score means indicate that the younger age group (below 35) are more concerned than those aged 36-45 and over 46 with the physical facilities and equipment of the local authority, the delivery of service as promised, the responsiveness of the organization and personal attention its provides. To improve the perceptions of younger adults, greater emphasis should be given to the improvement of physical appearance, service delivery process, and training of employees.

Education attainment of respondents has been found significant in discriminating three service quality factors. Customers with secondary qualifications are less concerned with the tangible elements of service than the other groups. Less educated customers are more concerned with service assurance, whereas those with higher educational attainments are more concerned with service reliability. Overall, these findings suggest three main areas for improvement - physical appearance, employees, and service performance. Apart from updating the appearance of physical facilities and equipment, customer perceptions could be enhanced by providing training programs for staffs on interpersonal communication skills, etiquette, and service knowledge.

As with any empirical study, this study also had certain limitations that must be considered when assessing the outcomes of its findings and implications. First, the study was limited to one public sector organization, therefore the reliability of the results restrict the extent to which the findings can be generalized across the public services in Thailand. Replication of this study with a larger, national, random sample would increase the generalizability of the results. Secondly, neither psychographics nor the full range of demographic characteristics (e.g. marital status, occupation, religion and social class) was included in this study. The inclusion of the full range of demographic and psychographic variables could yield greater insights into potential variations in customers' perceptions of service quality.

\section{References}

Andaleeb, S. S., \& Basu, A. K. (1994). Technical complexity and consumer knowledge as moderators of service quality evaluation in the automobile industry. Journal of Retailing, 70(4), 367-381. http://dx.doi.org/10.1016/0022-4359(94)90005-1

Berry, L. L., Parasuraman, A., \& Zeithaml, V. A. (1994). Improving service quality in America: lessons learned. Academy of Marketing Executive, 8(2), 32-52. http://dx.doi.org/10.5465/AME.1994.9503101072

Bowen, J. W., \& Hedges, R. B. (1993). Increasing service quality in retail banking. Journal of Retail Banking, 15(3), 21-28.

Brady, M. K., Cronin, J., J., \& Brand, R. R. (2002). Performance-only measurement of service quality: a replication and extension. Journal of Business Research, 55(1), 17-31. http://dx.doi.org/10.1016/S0148-29 63(00)00171-5

Brown, T. J., Churchill, G. A., \& Peter, J. P. (1993). Improving the measurement of service quality. Journal of Retailing, 69(Spring), 127-139. http://dx.doi.org/10.1016/S0022-4359(05)80006-5

Butler, D., Oswald, S. L., \& Turner, D. E. (1996). The effects of demographics on determinants of perceived health-care service quality: the case of users and observers. Journal of Management in Medicine, 10(5), 8-20. http://dx.doi.org/10.1108/02689239610146508

Carman, J. M. (1990). Consumer perceptions of service quality: an assessment of SERVQUAL dimensions. Journal of Retailing, 66(1), 33-55.

Cronin, J. J., \& Taylor, S. A. (1992). Measuring service quality: a reexamination and extension. Journal of Marketing, 56(3), 55-68. http://dx.doi.org/10.2307/1252296

Elliott, K. M. (1995). A comparison of alternative measures of service quality. Journal of Customer Service in 
Marketing and Management, 1(1), 33-44. http://dx.doi.org/10.1300/J127v01n01_04

Evans, M., Jamal, A., \& Foxall, G. (2006). Consumer behavior. West Sussex, UK: John Wiley \& Sons Ltd.

Fountain, J. E. (2001). Paradoxes of public sector customer service. Governance, 14(1), 55-73. http://dx.doi.org/ 10.1111/0952-1895.00151

Gilbert, G. R., Veloutsou, C., Goode, M. M. H., \& Moutinho, L. (2004). Measuring customer satisfaction in the fast food industry: a cross-national approach. Journal of Services Marketing, 18(5), 371-383. http://dx.doi.org/10.1108/08876040410548294

Grazier, K., Richardson, W., Martin, D., \& Diehr, P. (1986). Factors affecting choice of health care plans. Health Services Research, 20(6), 659-682.

Hair, J. F., Anderson, R., Tatham, R. \& Black, W. C. (1998). Multivariate data analysis (5th ed.). Upper Saddle River, NJ: Prentice Hall.

Hawkins, D. I., \& Mothersbaugh, D. L. (2010). Consumer behavior: building marketing strategy (11th ed). New York, NY: McGraw-Hill/Irwin.

Heskett, J. (1987). Lessons in the service sector. Harvard Business Review, 65(2), 118-126.

Hoch, S. J., \& Deighton, J. A. (1989). Managing what consumers learn from experience. Journal of Marketing, 53(2), 1-20. http://dx.doi.org/10.2307/1251410

Jain, S. K., \& Gupta, G. (2004). Measuring service quality: SERVQUAL vs. SERVPERF scales. Vikalpa, 29(2), 25-37.

Keaveney, S., \& Parthasarathy, M. (2001). Customer switching behavior in online services: an exploratory study of the role of selected attitudinal, behavioral, and demographic factors. Journal of the Academy of Marketing Science, 29(4), 374-390. http://dx.doi.org/10.1177/03079450094225

Kotler, P., \& Armstrong, G. (2008). Principles of marketing (12th ed.). Upper Saddle River, NJ: Pearson.

Krejcie, R. V., \& Morgan, D. W. (1970). Determining sample size for research activities. Educational and Psychological Measurement, 30(3), 607-610.

Ladhari, R. (2009). A review of twenty years of SERVQUAL research. International Journal of Quality and Service Sciences, 1(2), 172-198. http://dx.doi.org/10.1108/17566690910971445

McCarty, J. A., \& Shrum, L. J. (1993). The role of personal values and demographics in predicting television viewing behavior. Journal of Advertising, 22(4), 77-101.

Parasuraman, A., Zeithaml, V., \& Berry, L. (1985). A conceptual model of service quality and its implications for future research. Journal of Marketing, 49(Fall), 41-50. http://dx.doi.org/10.2307/1251430

Parasuraman, A., Zeithaml, V., \& Berry, L. (1988). SERVQUAL: a multiple item scale for measuring consumer perceptions of service quality. Journal of Retailing, 64(1), 12-40.

Parasuraman, A., Zeithaml, V. A., \& Berry, L. L. (1994). Reassessment of expectations as a comparison standard in measuring service quality: implications for further research. Journal of Marketing, 58(January), 111-124. http://dx.doi.org/10.2307/1252255

Paul, D. P. (2003). An exploratory examination of "SERVQUAL" versus "SERVPERF" for prosthetic dental specialists. Clinical Research and Regulatory Affairs, 20(1), 89-100. http://dx.doi.org/10.1081/CRP-120018 745

Pol, L. G. (1991). Demographic contributions to marketing: an assessment. Journal of the Academy of Marketing Science, 19(1), 53-59. http://dx.doi.org/10.1007/BF02723424

Spathis, C., Petridou, E., \& Glaveli, N. (2004). Managing service quality in banks: customers' gender effects. Managing Service Quality, 14(1), 90-102. http://dx.doi.org/10.1108/09604520410513695

Teicher, J., Hughes, O., \& Dow, N. (2002). E-government: a new route to public service quality. Managing Service Quality, 12(6), 384-393. http://dx.doi.org/10.1108/09604520210451867

Stafford, M. R. (1996). Demographic discriminators of service quality in the banking industry. Journal of Services Marketing, 10(4), 6-22. http://dx.doi.org/10.1108/08876049610124554

Zeithaml, V. A., Parasuraman, A., \& Berry, L. L. (1990). Delivering quality service: balancing customer perceptions and expectations. New York: The Free Press. 